\title{
Fundamentals of Odour Assessment in Slovenia
}

\author{
Martin Dobeic ${ }^{1}$ - Vincenc Butala ${ }^{2}$ - Matjaž Prek ${ }^{2}$ - Jan Leskovšek ${ }^{3}$ - Žiga Švegelj3,,* \\ 1 University of Ljubljana, Veterinary Faculty, Slovenia \\ 2 University of Ljubljana, Faculty of Mechanical Engineering, Slovenia
}

3 Studio okolje d.o.o., Slovenia

From a sociological and economic perspective, odour pollution is one of the most complex problems in the field of air quality. Therefore, various approaches and odour impact criteria are particularly relevant when assessing odour exposure in the areas of different land use. The number of odour assessment methods is limited, and the lack of analytical techniques to determine odour concentration makes odour assessment even more complex. It is essential to analyse the spatial and temporal distribution of odour concentrations in order to assess odour nuisance in the ambient air. Since sampling of odorous air in the field for subsequent determination of odour concentrations in a laboratory by dynamic olfactometry is time-consuming, two approaches are used to assess odour concentrations in ambient air: estimating odour concentration by field inspection and calculation of odour concentrations using atmospheric dispersion models. The latter is the most commonly used technique.

Our study aimed to provide fundamentals for an odour regulatory framework in Slovenia. While a multitude of approaches is presently applied to establish odour regulation framework, a broader approach remains lacking. Various odour emission sources were identified to evaluate available methods and techniques to assess odour impact. The impact area was selected to analyse and compare the impact of different odour sources in terms of odour concentration, odour frequency, odour offensiveness, land use, and receptor location. Finally, odour impact criteria were set according to odour offensiveness and concentration, percentile compliance level and land use.

Keywords: odour emission sources, odour concentration, odour nuisance, annoyance, impact assessment, offensiveness, 95th and $99^{\text {th }}$ percentiles of odour perception, mathematical dispersion model
Highlights
- The scope of the project was to provide fundamentals of odour assessment in Slovenia based on the evaluation of available methods and techniques and odour regulations in selected countries. The results presented in this paper are based on odour emission rates from various stationary industrial sources, in-field measurements of odour concentrations, and calculation of odour concentrations using the dispersion model.
- Evaluation and applicability of different odour assessment methods and related techniques were conducted in a selected assessment site with existing odour nuisance.
- Concentrations calculated using the dispersion model were compared against different odour impact criteria including odour concentration, odour offensiveness, percentile compliance level and land use.
- Odour impact criteria are recommended for odour regulatory purpose in Slovenia.

\section{INTRODUCTION}

Odour nuisance is an ecological, economic, and social problem. Most countries, especially in the EU, regulate odour pollution according to countryspecific odour impact criteria (OIC). These criteria consider the level of protection based on the land use, odour offensiveness, odour concentration threshold, and level of compliance expressed in terms of percentiles [1]. Due to meteorological and socioeconomical differences in the individual countries, odour impact criteria can vary considerably. In contrast to the analytical approach in which the particular odorous compound is measured using physical and chemical methods, odour concentration is determined using sensorial methods for which the basis of the measurement are human assessors. In the EU countries, the primary method used to determine odour concentrations is dynamic olfactometry method specified in European standard EN 13725 [2]. According to this method, odour concentration is measured under laboratory conditions at room temperature and normal atmospheric pressure. The measurements are performed by qualified panel members who detect the odour threshold in samples presented by dynamic olfactometer.

Several different assessment criteria should be considered simultaneously to assess odour impact adequately. The concentration of the odour is determined quantitatively, and the hedonic tone is determined qualitatively; the duration of each odour episode is also an important factor. Uncertainties associated with the determination of the odour emission rates from existing sources depend mostly on the type of a source since the determination of volume flow rate from area and volume sources is more complex compared to point sources. 
Determination of odour in ambient air by using the grid method [3] or portable olfactometer can be applied. However, both methods are time-consuming, and the former is also associated with high costs. Due to the lack of methods to determine the spatial distribution of odour concentration in the assessment area, dispersion modelling is the most widely used technique to assess odour impact from existing and new facilities [1]. A variety of input data, such as the type of emission source, odour emission rates, high-quality meteorological data, topographic data, and land use data, need to be provided to calculate odour concentration using models. Since the spatial distribution of odour concentration in ambient air, in addition to emission odour rate, depends mainly on the calculation of wind fields, coupling microscale diagnostic meteorological model and mesoscale prognostic meteorological model is recommended. Doing so allows for vertical temperature profile, related information on temperature inversion, and vertical wind profile to be used in the meteorological model on a local scale. Although the use of dispersion model has certain advantages over field inspection methods, the inaccuracy of calculated odour concentration can be significant. Therefore, it is highly relevant to compare and verify calculated odour concentrations against those obtained by field inspection.

In general, odour dispersion modelling is similar to dispersion modelling of various pollutants in ambient air. However, unlike the majority of pollutants, the odour can be perceived by the human nose. The response of an individual to odour exposure is subjective and depends on numerous factors related to the physiological state of the receptor. While breathing normally, an average healthy adult has a respiratory rate of 12 to 18 breaths per minute, meaning that the duration of a single breath is approximately 3 to 5 seconds [4]. This indicates that odour concentrations should be considered on the time scale of seconds instead of hours. To provide a short-term odour peak concentration, the so-called peak-to-mean method is used [5]. According to this method, odour peak concentration is calculated based on hourly mean concentration using the peak-to-mean ratio, in which the latter is defined as a relationship between peak and mean odour concentration. Several approaches are used to estimate the peak-to-mean ratio. For instance, in Germany, the ratio is defined as a constant value of 4 [6]. Many recent studies suggest that the ratio depends on atmospheric stability, the distance from the odour source, and on the length of the selected time interval to calculate short-term odour peak concentrations.

A relationship between peak and mean concentration is expressed as a power function [7]:

$$
R_{0}=\frac{C_{p}}{\bar{C}}=\left(\frac{t_{m}}{t_{p}}\right)^{a},
$$

where $R_{0}$ is a peak-to-mean factor, $C_{p}$ short-term peak odour concentration, $\bar{C}$ long-term mean concentration, $t_{m}$ long-term averaging time (usually 1 hour), $t_{p}$ short-term averaging time, and exponent a is empirically determined atmospheric-stability dependent exponent factor [8]. During stable atmospheric conditions, the odour dispersion is limited and therefore, the ratio is small. In contrast, during the unstable atmospheric condition, the odour disperses in ambient air more sufficiently, and hence the ratio is significant. Since odour peak concentration is also dependent on the distance from the odour emission source, Eq. (1) can be formulated as [9] to [11]:

$$
R(r)=1+\left(R_{0}-1\right) \cdot e^{-0.7317 \frac{T(r)}{t_{l}}},
$$

$T(r)$ represents the particle's travel time calculated using the distance from the odour source and the wind speed. Variable $t_{l}$ is a measure of a Lagrangian time scale [12]. The latter represents the time over which the velocity of a particle is self-correlated or roughly the time over which a particle maintains its initial velocity before experiencing a turbulent collision [13]. The Lagrangian time scale is defined as a ratio between wind speed variance and the rate of dissipation of turbulent energy:

$$
t_{l}=\frac{\sigma^{2}}{\varepsilon}=\frac{\frac{1}{3}\left(\sigma_{u}^{2}+\sigma_{v}^{2}+\sigma_{w}^{2}\right)}{\frac{1}{k z}\left(\frac{\sigma_{w}}{1.3}\right)^{3}},
$$

where $\sigma_{u}, \sigma_{v}, \sigma_{w}$, are variances of wind speed by components, $k$ is the von Karman constant, and variable $z$ height of individual or more specifically the receptor's nose. According to [14], the distribution of odour concentration within an hour can be fitted using the modified two-parameter Weibull probability density function:

$$
\begin{gathered}
p(c)=\lambda k(\lambda k)^{k-1} e^{-(\lambda c)^{k},} \\
k=\left(\frac{\bar{C}}{\sigma}\right)^{1.086},
\end{gathered}
$$




$$
\lambda=\frac{\Gamma(1+1 / k)}{\bar{C}} .
$$

Eqs. (5) and (6) are used to calculate shape parameters $k$ and $\lambda$, where a variable $\bar{C}$ is hourly mean concentration, $\sigma$ standard deviation of odour concentration within an hour, and $\Gamma$ Gamma function. Shape parameters $k$ and $\lambda$ are computed in post-processing using an analytical approach. Once these factors are computed, the $90^{\text {th }}$ percentile of the cumulative frequency distribution of odourconcentration fluctuations or the peak-to-mean ratio is determined using:

$$
R_{90}=\frac{(-\ln 0.1) \frac{1}{k}}{\lambda \bar{C}},
$$

Such an approach is practical, as there is no need to modify the source code of the dispersion model, and it can be used in combination with various dispersion models. It should be noticed that odour-hour concept is applied in a German guideline VDI 3940 [15], where an odour-hour is defined as an hour that has recognizable odour for at least $10 \%$ of the time [16], which implies that the $90^{\text {th }}$ percentile of cumulative frequency distribution has to be calculated.

Providing methodology to assess odour impact and to ensure an adequate regulatory framework remains a relevant challenge on a global scale. While a multitude of different methodologies is presently applied to assess odour impact, a broader approach to this problem remains lacking. The so-called CICOP approach was established to evaluate the odour impact [17]. According to this approach, the concentration, intensity, character, offensiveness, and persistence of an odour should be determined to assess odour impact. A similar but complementary is the FIDOL approach, in which FIDOL refers to odour frequency, intensity, duration, offensiveness, and location of the receptor [18] and [19]. The FIDOL approach is the basis of numerous regulatory frameworks and the concept of odour impact criteria [20]. Once compared to the findings of dose-response studies, which analyse the population response to the odour exposure, the odour impact criteria can be applied to the regulatory framework to limit odour nuisance from existing facilities or to prevent odour nuisance in the planning stage of a new facility.

\section{MATERIALS AND METHODS}

\subsection{Odour Emission Sources}

In general, odour nuisance is caused by odour-emitting sources of anthropogenic origin. In contrast to odour emissions from natural sources, the odour emitted from industry can be regulated to prevent and minimize or at least mitigate odour impact. In this study, the odour impact of four different sectors classified according to similar functions was investigated (e.g., food, metal, rendering, waste services).

Due to the differences in odour characteristics and consequently odour impact, odour samples at 12 odour-emitting facilities from a total of 17 different odour sources were collected. These differ in terms of the type of a source (e.g., point, area, and volume), hedonic tone of the odour, and odour emission rate. The odour samples were classified into four categories from least to most offensive odour, based on the

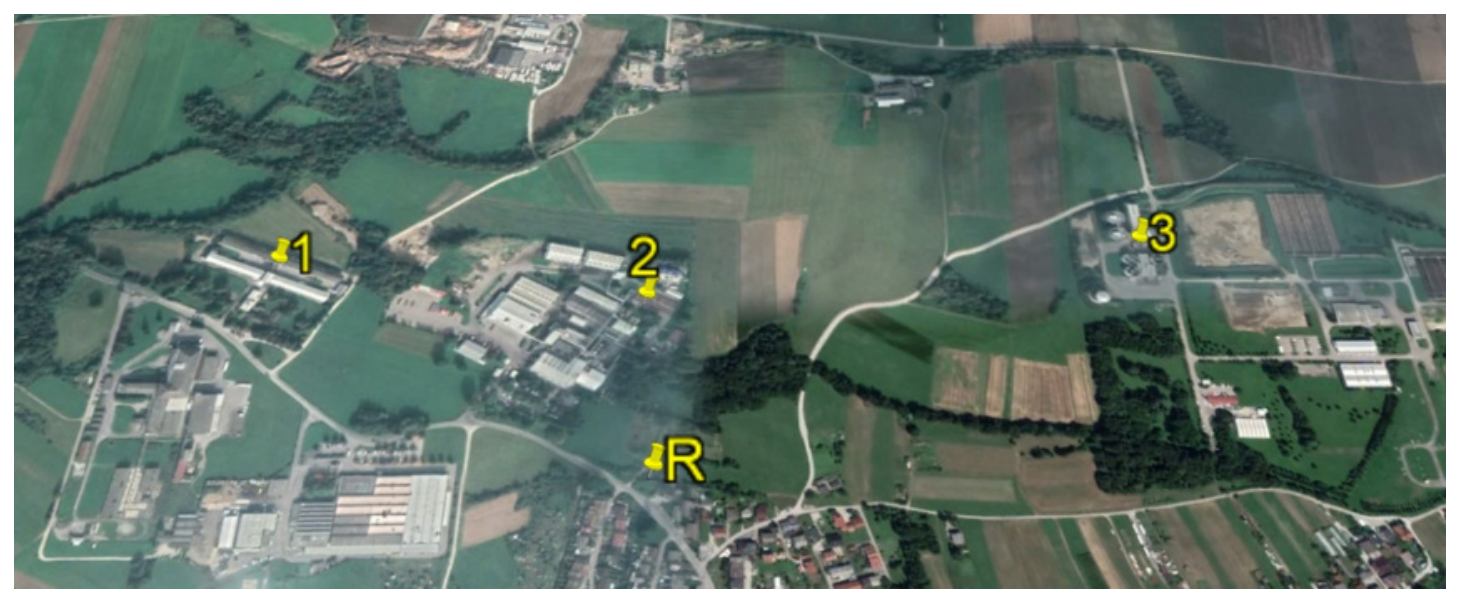

Fig. 1. An assessment area including a measurement site, location of the nearest sensitive receptor (marked with R) and odour emission sources, e.g., hen farm (marked with number 1), rendering plant (2), and municipal wastewater treatment plant (3) 
hedonic tone (Table A1 in Appendix). Additionally, source data, such as location, dimension, height, as well as volume flow velocity, temperature and humidity of gas sample, were collected. Odour concentrations were determined under laboratory conditions using dynamic olfactometry, by which odorous samples were presented to qualified panel members. Odour emission rates were calculated using odour concentrations and characteristics of emission source.

In order to evaluate the impact of 17 different odour sources, an assessment area was selected. Measurements of meteorological parameters were carried out at a measurement site to obtain representative site-specific meteorological data. Applying such an approach enables the comparison of odour impact caused by different emission sources. The odour impact assessment was conducted in terms of odour concentration, odour offensiveness, different peak-to-mean ratios, and the residential area in which sensitive receptors are located. In the selected assessment area, three existing odour emitting facilities are located, while the nearest receptor is located at a distance of 200 metres from emission source, as shown in Fig. 1.

\subsection{Meteorological Conditions}

The dispersion of pollution in the atmosphere depends mainly on two physical processes: the advection of pollution downwind of the source and the dispersion of pollution transverse to the wind direction. While three-dimensional wind fields are required to describe advection, the dispersion depends on the atmospheric stability. Meteorological parameters, such as wind, air temperature, relative humidity, and air pressure, were recorded for 11 months at 10-minute intervals, to obtain representative site-specific meteorological data. Wind measurements in three dimensions were carried out using an ultrasonic anemometer. The measure of atmospheric stability in terms of Monin Obukhov length and standard deviation of vertical wind speed was derived from data collected by an ultrasonic anemometer. The analysis of meteorological data presented in Fig. 2 indicates a dominant north-east (N-E) winds and frequent low wind speeds. During the measurement period, the wind speed was below 1 $\mathrm{m} / \mathrm{s} 49 \%$ of the time. Due to a substantial percentage of time with low wind speeds and consequently a stable condition in the atmosphere, the dispersion of pollution is limited. Meandering, i.e., low-frequency horizontal wind oscillations, weak, layered, and intermittent turbulence occur in such meteorological conditions [21], which results in inhomogeneous and non-stationary wind fields, which are more complex to compute.
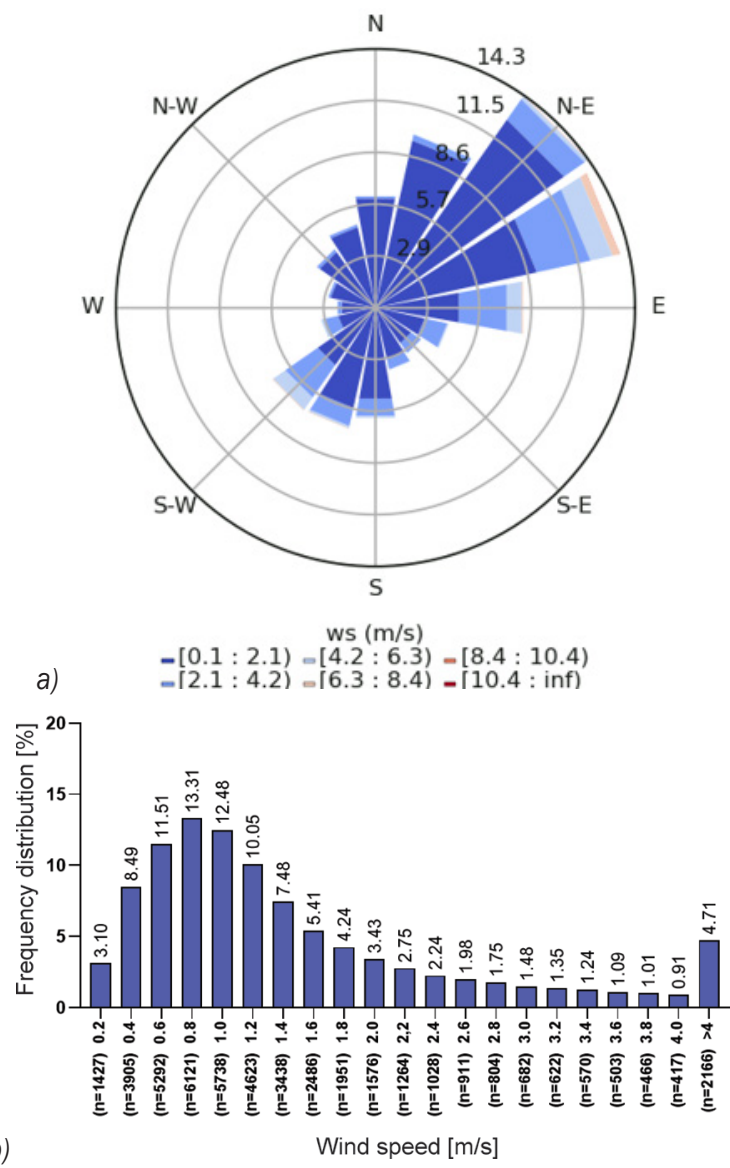

Fig. 2. a) A wind rose, and b) wind speed (ws) frequency distribution at the measurement site in which parameter $n$ represents the number of measurements in each class interval

\subsection{In-Field Determination of Odour}

The method of in-field determination of odour concentration using portable olfactometer is based either on diluting the ambient odorous air by odourless air compressed in a gas cylinder or by filtering ambient odorous air using carbon adsorption bed [22]. Both approaches allow the determination of odour concentration in-situ, withdrawing the need of collecting odorous air in a sampling bag for subsequent olfactometry in a laboratory. The determination of odour concentration is conducted by an assessor, who is qualified according to requirements specified in the EU standard of dynamic olfactometry. The main disadvantage of portable olfactometers are their uncertainties associated with dilution technique as inaccuracy of dilution ratios 
can be significant. Due to this issue, the performance of portable olfactometers has to evaluated using the gas analyser and certified test gas on a regular basis. Although in-field olfactometry is not standardized, it can be useful as complementary information for validation of dispersion models.

Prior to field inspection, the performance of portable olfactometer was evaluated using the calibrated gas analyser and a certified gas cylinder containing hydrogen sulphide. Six series of field inspection was conducted in a so-called Assessment area (Fig. 1), where 26 odour assessment locations within a grid of $2.65 \mathrm{~km} \times 1.4 \mathrm{~km}$ with a resolution of $70 \mathrm{~m}$ were selected. In each of these locations, odour concentration over a period of 3 to 10 minutes was assessed, while the duration of each field inspection was 2 hours. In order to determine odour peak concentration, field inspections were performed considering local meteorological conditions and the official weather forecast of Slovenian environmental agency.

\subsection{Dispersion Modelling}

The modelling system CALPUFF/CALMET [23] and [24], which consists of a Lagrangian puff dispersion model and diagnostic mass-consistent meteorological model, was applied to assess the spatial and temporal distribution of odour concentrations. According to the EPA (US), the CALPUFF/CALMET modelling system is recommended for simulating the dispersion of pollutants over complex terrain, where topographic features might generate light or calm local winds and circulations. In order to compute three-dimensional wind fields, a microscale CALMET diagnostic model and mesoscale ALADIN/SI numerical weather prediction model were coupled. As the input for the CALMET model, the meteorological data series including site-specific meteorological data obtained by ground station and vertical temperature and wind profiles computed with the ALADIN/SI numerical weather prediction model was provided.

For the purpose of the odour impact evaluation in the assessment area, the modelling domain in the size of $4.8 \mathrm{~km} \times 4.8 \mathrm{~km}$ and horizontal grid resolution of $40 \mathrm{~m}$ was introduced. The modelling domain and grid resolution as configurated in CALPUFF/CALMET modelling system are illustrated in Fig. 3b, while the grid resolution of the mesoscale numerical prediction model, which is $4.4 \mathrm{~km}$, is illustrated in Fig. 3a. Fig. $3 \mathrm{~b}$ also shows areas of different land use; residential areas are coloured in grey, cultivation areas in brown, and forest in green. The red placemark represents the emission source location. This location was chosen to assess and compare the odour impacts of 17 different emission sources.

\subsection{Odour Impact Criteria}

The odour impact of 17 emission sources specified in Section 2.1 was evaluated using so-called odour-hours, which implies that the $90^{\text {th }}$ percentile of cumulative frequency distribution has to be calculated.

Therefore, to assess the odour impact adequately, it is essential to provide peak concentrations within an hour. These are calculated by utilizing hourly odour concentrations using the peak-to-mean method. The relationship between peak concentration and hourly average concentration is known as the peak-to-mean ratio $(R)$. Due to a comparison of different approaches to assessing the peak-to-mean ratio, hourly odour concentrations were modified applying constant peak-to-mean $R$ factor [6], empirically determined $R$ factor, and analytically derived $R$ factor. According to [7], $R$ factor considers atmospheric stability, while $R$ factor according to [9] and [14] considers atmospheric stability and distance from an emission source. Comparison of calculated $R$ factors using

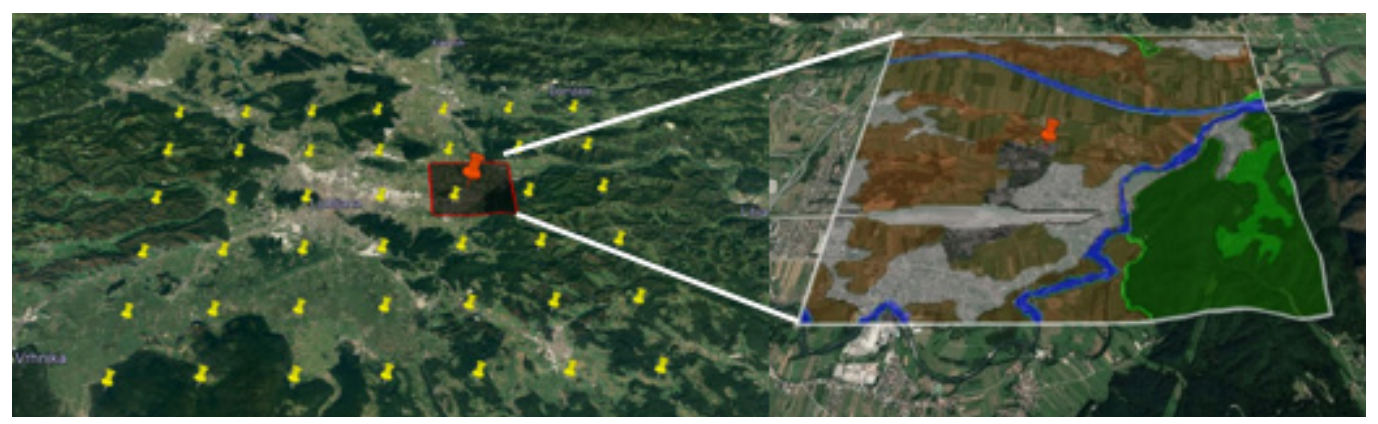

a)

b)

Fig. 3. Modelling domain; a) horizontal grid resolution, b) emission source location, and land use 
different methods is presented in Table 1 , where $t_{p}$ presents short-term averaging time. Note that the dispersion model simulations provided mean odour concentrations for an averaging time of an hour.

Table 1. Comparison of calculated $R$ factors using different methods

\begin{tabular}{lcccccccc}
\hline & \multicolumn{8}{c}{ Short-term averaging time $t_{p}$} \\
\cline { 2 - 9 } Method & \multicolumn{2}{c}{$5 \mathrm{~s}$} & \multicolumn{2}{c}{ 1 minute } & \multicolumn{2}{c}{3 minutes } & \multicolumn{2}{c}{6 minutes } \\
\cline { 2 - 9 } & $\min$ & $\max$ & $\min$ & $\max$ & $\min$ & $\max$ & $\min$ & $\max$ \\
\hline$[7]$ & 3.3 & 87.7 & 2.1 & 16.2 & 1.7 & 7.4 & 1.5 & 4.8 \\
\hline$[9]$ & 1.0 & 84.8 & 1.0 & 15.7 & 1.0 & 7.4 & 1.0 & 4.4 \\
\hline$[14]$ & 1.5 & 169.0 & 1.5 & 17.9 & 1.5 & 7.0 & 1.5 & 4.0 \\
\hline
\end{tabular}

Regarding Table 1, the differences between minimum and maximum $R$ factors can be significant. Since it was concluded that modelled odour concentrations utilizing a short-term time interval of less than 6 minutes would be overestimated, we opted for the latter.

Two levels of protection against odour nuisance based on land use were introduced to evaluate the odour impact in the assessment area. The highest level of protection includes residential areas, holiday homes, health infrastructure, and social institutions, recreation and sports areas, parks, gardens, cemeteries, and tourist resorts. In contrast, the low level of protection includes various areas with industrial facilities, roads, agricultural land, and mining areas.

Furthermore, the odours were classified according to their hedonic tone (offensiveness), which is a measure of pleasantness or unpleasantness of an odour at a given concentration. The classification of odour emission sources, according to the odour offensiveness, is summarized in Table 2.

Table 2. Classification of emission sources according to the odour offensiveness

\begin{tabular}{ll}
\hline $\begin{array}{l}\text { Odour } \\
\text { offensiveness } \\
\text { level }\end{array}$ & $\begin{array}{l}\text { Emission } \\
\text { source }\end{array}$ \\
\hline Low & $\begin{array}{l}\text { Fodder mixing plant, Foundry, Bakery, } \\
\text { Coffee roasting facility }\end{array}$ \\
\hline Medium & $\begin{array}{l}\text { Poultry farm, Broiler farm, } \\
\text { Municipal wastewater treatment plant }\end{array}$ \\
\hline High & Pig farm, Red meat slaughterhouse, Brewery \\
\hline Extreme & Biogas plant, Rendering plant \\
\hline
\end{tabular}

The criteria for the classification of odour sources in terms of odour offensiveness were based on VDI 3882, Part 2 [25] and our experiences since all of the emission sources are the reason for a large number of public complaints in Slovenia.
Finally, the odour impact assessment of 17 emission sources was conducted considering the odour concentration threshold, odour offensiveness and, percentile compliance level. The frequency of odour episodes was analysed through variation of the percentile level.

\subsection{Appendix}

The appendix to the article contains Table A1 as odour emission source classification with data on emission sources. Fig. A1 represents a comparison of odour emission rates. In the appendix evaluation between groups of odour emission rates and between groups of in-field odour concentrations using portable olfactometer are included.

\section{RESULTS AND DISCUSSION}

\subsection{Determination of Odour Emission Rates}

While uncertainties related to the determination of odour emission rates from point and area sources are fairly manageable, the same cannot be said for volume sources where fugitive emissions frequently occur. A total of 17 different emission sources observed in this study. They were collected at 11 point sources and 6 area sources (Table A1: Types and dimensions of emission sources and 3 volume sources described in the appendix). It should be noted that according to [26] emission sources can be classified as active or passive, depending on the velocity of the waste gas at the release. If the velocity is greater than $30 \mathrm{~m} / \mathrm{h}$, the source is considered active; otherwise, the source is passive. According to this definition, ventilation ducts at the hen, broiler, and pig farm, bakery, coffee roasting plant, brewery, foundry, and stack at biogas power plant were classified as point sources, the biofilter at a rendering facility, oxygenation and sludge tanks at the wastewater treatment plant, fodder mixing plant, and mixing tank at biogas plant as area sources, while storage facilities for sludge and hides at a rendering facility, and a slaughterhouse as volume sources. (Table A1 in the appendix: Types and dimensions of emission sources, and measurements of temperature and humidity of waste gas, Fig. A1 in the appendix: Comparison of odour emission rates). Emission rates from these sources are illustrated in Fig. 4.

The comparison shows that odour emissions from sources such as biogas power plant, brewery, coffee roasting plant and pig farm are extremely high and higher $(P=0.076)$ than the others. If a facility generating odour nuisance is exposed in public, 


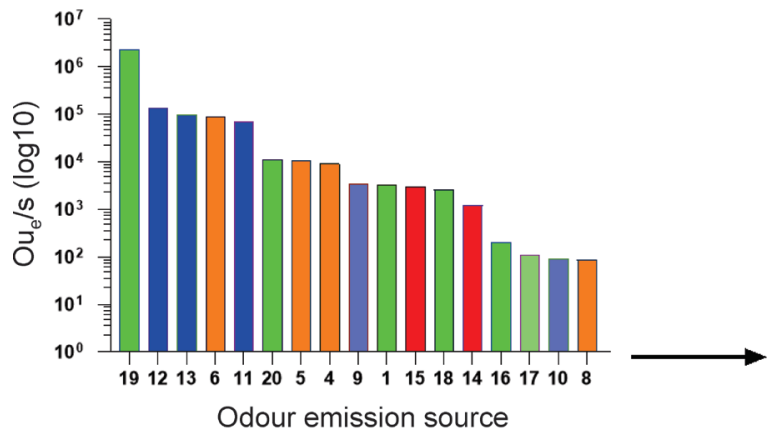

a)

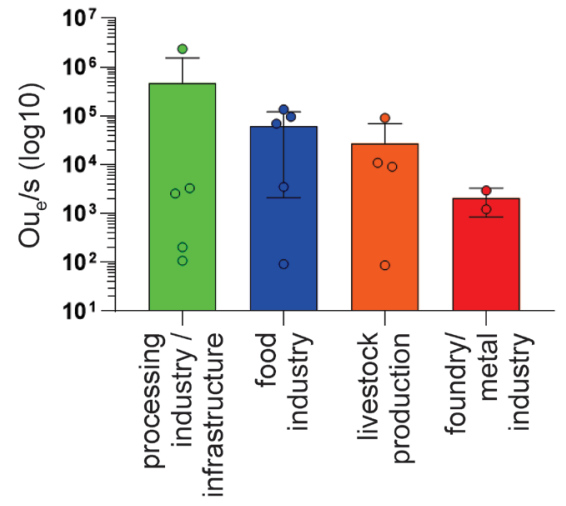

b)

Fig. 4. a) Odour emission ( $\left.\mathrm{O} u_{e} / \mathrm{s}\right)$ by source classification: biofilter at animal by-products processing plant (1), hen farm (4), broiler farm (5), pig farm (6), fodder mixing plant (8), bakery: ventilation duct - baking (9), ventilation duct- mixing process (10), ventilation duct at coffeeroasting plant (11), brewery ventilation ducts $(12,13)$, foundry - ventilation ducts on the rooftop $(14,15)$, sludge thickener at the municipal wastewater treatment plant (16), sludge thickener at the municipal wastewater treatment plant (17), oxygenation tank at the municipal wastewater treatment plant (18), stack at the biogas power plant (19), mixing tank at the biogas power plant (20); b) the mean value of emissions grouped by industry type

authorities take action and start the abatement process to tackle odour nuisance. Among all emission sources, estimating emission rates from volume sources was most challenging as fugitive emissions were identified. Therefore, reverse modelling was applied to evaluate emission rates from those sources. However, this is not the optimal solution to the problem as uncertainties associated with such an approach can be significant. An odour concentration as $\mathrm{Ou}_{\mathrm{e}} / \mathrm{m}^{3}(\mathrm{Ou}$ - European odour unit per cubic metre, e - EROM (European Reference Odour Mass)) and odour emission rate as $\mathrm{Ou}_{\mathrm{e}} / \mathrm{s}$ (European odour unit per second) can be determined more adequately by converting a volume source into a point source. This can be achieved by providing negative air pressure, i.e., to provide lower pressure than of the surroundings, and use single or multiple stacks to control the release of odorous gas.

\subsection{In-Field Olfactometry}

The results of field inspection using portable olfactometer in the assessment area indicate odour nuisance in the vicinity of all three odour sources, i.e., hen farm, rendering plant, and wastewater treatment plant, present in this area (see Fig. 1). The highest odour concentrations were estimated adjacent to the rendering plant, which were significantly higher $(P<$ 0.0001) than the other odour concentrations adjacent to the hen farm and wastewater treatment plant (Fig. 5). The odour peak concentration of $19 \mathrm{Ou}_{\mathrm{e}} /$ $\mathrm{m}^{3}$ was assessed outside the rendering facility fence line 100 metres from the majority of odour sources. Further downwind from rendering facility, odour concentrations decreased rapidly. At a distance of 200 metres odour concentrations did not exceed $7 \mathrm{Ou}_{\mathrm{e}} / \mathrm{m}^{3}$, at the distance of $300 \mathrm{~m}$, where the nearest sensitive receptor is located $3 \mathrm{Ou}_{\mathrm{e}} / \mathrm{m}^{3}$, and at a distance of $400 \mathrm{~m} 2 \mathrm{Ou}_{\mathrm{e}} / \mathrm{m}^{3}$. At the distance of $500 \mathrm{~m}$, the odour concentrations did not exceed the odour threshold of 1 $\mathrm{Ou}_{\mathrm{e}} / \mathrm{m}^{3}$ during field inspections.

\subsection{Dispersion Modelling}

The results of dispersion modelling were analysed and compared in terms of land use (level of protection against odour nuisance), odour offensiveness, and level of compliance. The latter was expressed in percentiles and varied in the range between $99^{\text {th }}$ and $90^{\text {th }}$ percentile. Odour concentrations were compared at the nearest sensitive receptor, which is located 300 $\mathrm{m}$ from the rendering plant. Fig. 6 illustrates odour concentrations at the $99^{\text {th }}$ and $95^{\text {th }}$ percentiles in the assessment area where 3 existing odour sources (i.e. hen farm, the rendering plant and municipal wastewater treatment plant) are located. The comparison shows that odour concentrations at $99^{\text {th }}$ percentile exceed odour threshold of $1 \mathrm{Ou}_{\mathrm{e}} / \mathrm{m}^{3} 2000$ $\mathrm{m}$ downwind of rendering facility, while those at $95^{\text {th }}$ percentile exceeded $1 \mathrm{Ou}_{\mathrm{e}} / \mathrm{m}^{3} 1000 \mathrm{~m}$ downwind of the rendering facility. 


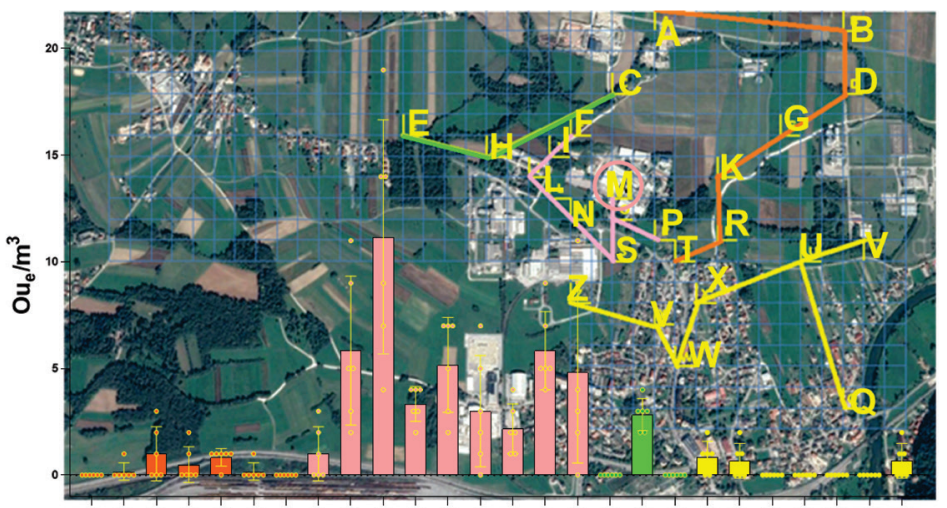

A B D G K R T P O M S N L J I F C H E U V X Y W Q Z

\section{Measuring location}

Fig. 5. In-field odour concentration assessment using portable olfactometer. Odour concentration was assessed at 26 odour locations within a grid of $2.65 \mathrm{~km} \times 1.4 \mathrm{~km}$ and a resolution of $70 \mathrm{~m}$; green lines indicate the alleged impact of the chicken farm, pink lines indicate the impact of the rendering plant, orange lines indicate the alleged impact of the wastewater treatment plant, yellow lines indicate the impact to nearby settlements; $M$ indicates the highest measured concentration near the biofilter of the rendering plant

a)

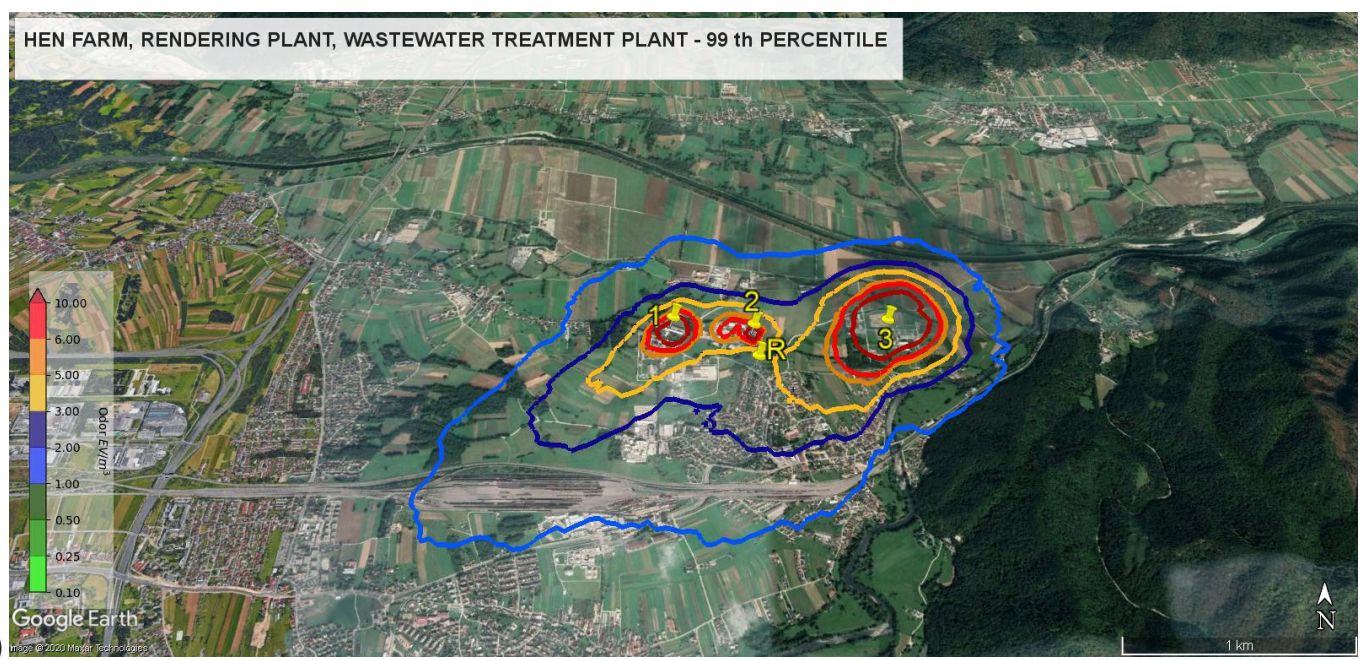

b)

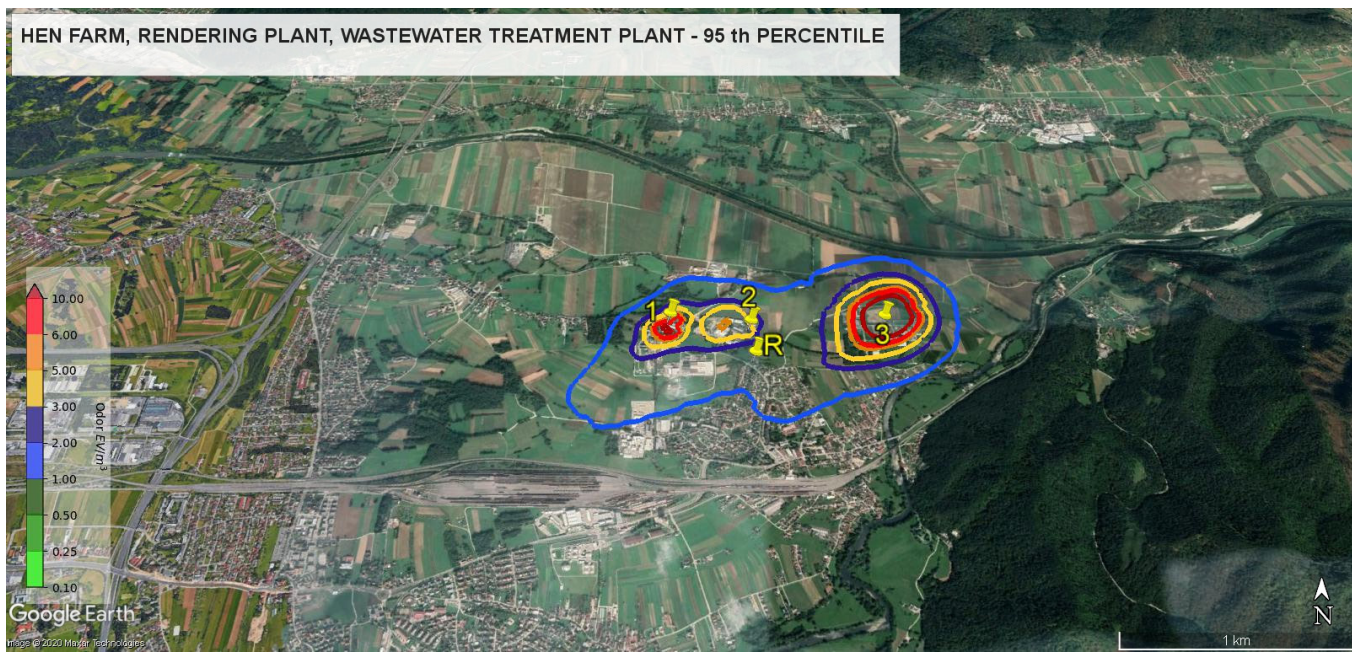

Fig. 6. Odour impact in terms of odour concentrations and percentile compliance level in the Assessment area which includes 3 odour sources, i.e., hen farm, the rendering plant, and municipal wastewater treatment plant (these are also shown in Fig. 1);

a) illustrates odour concentrations at the 99th percentile, while b) at 95th the percentile 
Furthermore, the odour impact of the other odour sources listed in Section 2.1. was evaluated. The impact of each odour source was evaluated in the Assessment area. Odour sources were positioned in the location of the rendering facility. Comparison of odour concentrations at the nearest sensitive receptor $300 \mathrm{~m}$ downwind of the source is shown in Fig. 7, where odour offensiveness thresholds are introduced. Fig. 7a shows that odour concentrations generated by the coffee roasting facility at the $99^{\text {th }}$ and 95th percentiles would exceed $4 \mathrm{Ou}_{\mathrm{e}} / \mathrm{m}^{3}$, which was recommended threshold concentration for odour with low offensiveness. Odour concentrations generated by a wastewater treatment plant would exceed threshold

a)

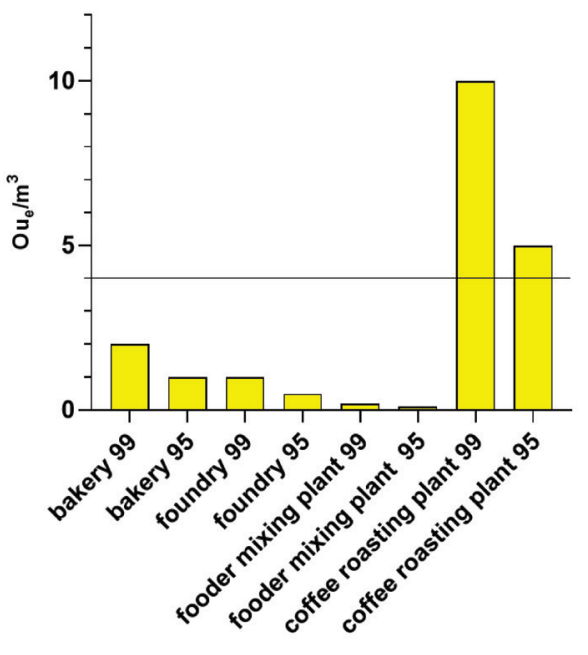

b)
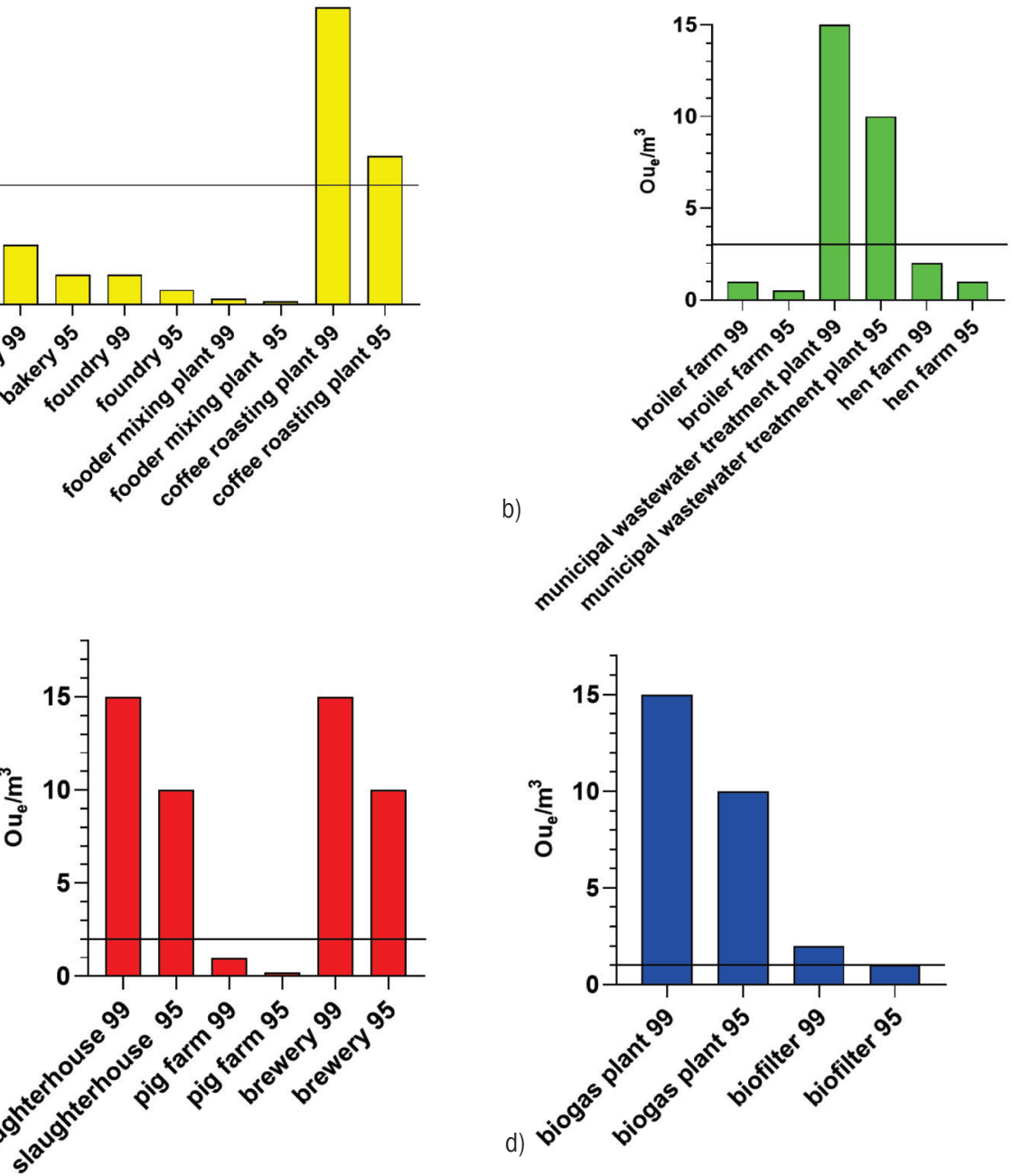

d)

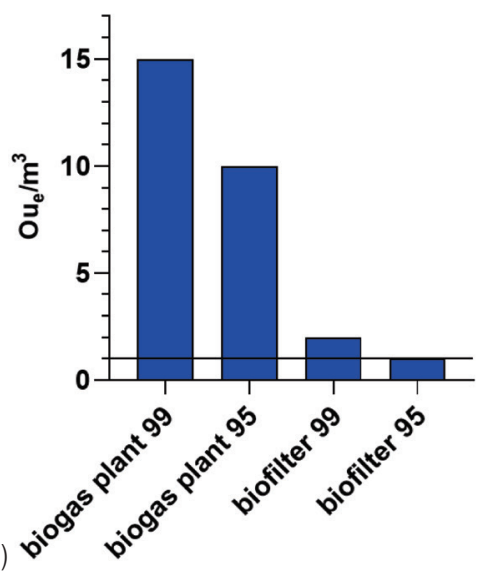

concentration of $3 \quad \mathrm{Ou}_{\mathrm{e}} / \mathrm{m}^{3}$ at both $99^{\text {th }}$ and $95^{\text {th }}$ percentile, while odour impact of other odour sources in the group of moderately offensive odours would be within recommended threshold values. Highly (Fig. 7c) and extremely (Fig. 7d) offensive odours generated by the slaughterhouse, brewery, biogas power plant, and biofilter at rendering facility would exceed recommended odour threshold of $2 \mathrm{Ou}_{\mathrm{e}} / \mathrm{m}^{3}$ and $1 \mathrm{Ou}_{\mathrm{e}} / \mathrm{m}^{3}$ at $99^{\text {th }}$ and $95^{\text {th }}$ percentile. It can be concluded that these sources would exceed threshold limits even if the location of the nearest sensitive receptor would be within level II of protection against odour nuisance.

Fig. 7. Odour concentrations in terms of odour compliance level in percentile and odour offensiveness; a) a threshold of $10 u_{e} / m^{3}$ for extremely offensive odours, b) a threshold of $20 u_{e} / m^{3}$ for highly offensive odours, c) a threshold of $3 \mathrm{Ou} / \mathrm{m}^{3}$ for moderately offensive odours, and d) a threshold of $40 \mathrm{ue}_{e} / \mathrm{m}^{3}$ for low offensive odours; the nearest sensitive receptor located $300 \mathrm{~m}$ downwind of the odour source 
On the basis of presented analysis, odour impact criteria for existing and new facilities were recommended to establish a regulatory framework. The impact criteria are summarized in Tables 3 and 4.

Table 3. Odour impact criteria for level I protection areas

\begin{tabular}{lccc}
\hline $\begin{array}{l}\text { Odour } \\
\text { offensiveness }\end{array}$ & $\begin{array}{c}\text { Threshold } \\
\text { concentration } \\
{\left[\mathrm{Ou}_{\mathrm{e}} / \mathrm{m}^{3}\right]}\end{array}$ & $\begin{array}{c}\text { Percentile } \\
\text { compliance level, } \\
\text { existing facilities }\end{array}$ & $\begin{array}{c}\text { Percentile } \\
\text { compliance level, } \\
\text { new facilities }\end{array}$ \\
\hline low & 4 & 98 & 99 \\
\hline medium & 3 & 98 & 99 \\
\hline high & 2 & 98 & 99 \\
\hline exceptional & 1 & 98 & 99 \\
\hline
\end{tabular}

Table 4. Odour impact criteria for level II protection areas

\begin{tabular}{lccc}
\hline $\begin{array}{l}\text { Odour } \\
\text { offensiveness }\end{array}$ & $\begin{array}{c}\text { Threshold } \\
\text { concentration } \\
{\left[\mathrm{Ou}_{\mathrm{e}} / \mathrm{m}^{3}\right]}\end{array}$ & $\begin{array}{c}\text { Percentile } \\
\text { compliance level, } \\
\text { existing facilities }\end{array}$ & $\begin{array}{c}\text { Percentile } \\
\text { compliance level, } \\
\text { new facilities }\end{array}$ \\
\hline low & 4 & 90 & 95 \\
\hline medium & 3 & 90 & 95 \\
\hline high & 2 & 90 & 95 \\
\hline exceptional & 1 & 90 & 95 \\
\hline
\end{tabular}

\section{CONCLUSION}

Various emission sources were identified in terms of odour emission, odour offensiveness, and type of emission source in order to address odour management. Among several emission sites, a single assessment area was selected to evaluate the impact of the individual odour source. The odour impact of 17 emission sources was compared against commonly used criteria, which is provided by regulatory frameworks to assess the impact of existing facilities or to prevent potential odour nuisance in the planning stage of a new facility. As the representativeness of dispersion model simulations depends mainly on the input data, 11-month site-specific meteorological data, type of land use and topographical data were provided. A diagnostic meteorological model and a mesoscale prognostic meteorological model were coupled to compute wind fields. Hourly mean concentrations were calculated using the dispersion model, while short-term peak concentrations were provided using various peak-to-mean methods. Additionally, in-situ odour concentrations were estimated using portable olfactometer.

Odour impacts of emission sources were compared in terms of odour concentration generated by a particular source, odour offensiveness and level of compliance in percentile. Whereas the latter was varied in the range from $90^{\text {th }}$ to $99.9^{\text {th }}$ percentiles, odour concentration was analysed 300 metres downwind of emission source at the nearest receptor. On the basis of this analysis, odour impact criteria for a different type of land use and existing or new facility were specified.

While dispersion models are a very useful tool for odour impact assessment, the verification of their results requires more research in the future. In particular, the assessment of odour impact by various field inspection methods and dose-response studies should be conducted.

\section{ACKNOWLEDGEMENTS}

The research was funded by the Ministry of Environment and Spatial Planning of the Republic of Slovenia.

\section{APPENDIX}

Table A1. Odour emission source classification with data of emission sources: biofilter at animal by-products processing plant (1), storage facility for hides at animal by-products processing plant (2), storage facility for waste sludge at animal byproduct-processing plant (3), hen farm (4), broiler farm (5), pig farm (6), slaughterhouse (7), fodder mixing plant (8), bakery: ventilation duct - baking (9), ventilation duct - mixing process (10), ventilation duct at coffee roasting plant (11), brewery ventilation ducts $(12,13)$, foundry - ventilation ducts on the rooftop (14, 15), sludge thickener at the municipal wastewater treatment plant (16), sludge thickener at the municipal wastewater treatment plant (17), oxygenation tank at the municipal wastewater treatment plant (18), stack at biogas power plant (19), mixing tank at biogas power plant (20)

\begin{tabular}{cccccccccc}
\hline $\begin{array}{l}\text { Emission } \\
\text { source }\end{array}$ & $\begin{array}{c}\text { Type of } \\
\text { emission } \\
\text { source }\end{array}$ & $\begin{array}{c}\text { Source } \\
\text { height } \\
{[\mathrm{m}]}\end{array}$ & $\begin{array}{c}\text { Cross section / } \\
\text { area / volume of } \\
\text { the source }\end{array}$ & $\begin{array}{c}\text { \# of } \\
\text { sources }\end{array}$ & $\begin{array}{c}\text { Waste gas } \\
\text { temperature } \\
{\left[{ }^{\circ} \mathrm{C}\right]}\end{array}$ & $\begin{array}{c}\text { Relative } \\
\text { humidity of } \\
\text { waste gas }[\%]\end{array}$ & $\begin{array}{c}\text { Flow } \\
\text { rate } \\
{\left[\mathrm{m}^{3} / \mathrm{h}\right]}\end{array}$ & $\begin{array}{c}\text { Odour } \\
\text { concentration } \\
{\left[\mathrm{Ou} / \mathrm{m}^{3}\right]}\end{array}$ & $\begin{array}{c}\text { Odour } \\
\text { emission rate } \\
{[\mathrm{Ou} / \mathrm{s}]}\end{array}$ \\
\hline 1 & area & 2 & $1.000 \mathrm{~m}^{2}$ & 1 & 23.7 & 78 & 95.000 & 126 \\
\hline 2 & volume & $/$ & $20.000 \mathrm{~m}^{3}$ & 1 & $/$ & $/$ & $/$ & $/$ & 954 \\
\hline 3 & volume & $/$ & $12.000 \mathrm{~m}^{3}$ & 1 & $/$ & $/$ & $/$ & 2.048 \\
\hline 4 & point & $1 ; 3 ; 6$ & $0.16 \mathrm{~m}^{2}$ & 36 & 30.5 & 49 & 5.040 & 181 \\
\hline
\end{tabular}




\begin{tabular}{|c|c|c|c|c|c|c|c|c|c|}
\hline $\begin{array}{l}\text { Emission } \\
\text { source }\end{array}$ & $\begin{array}{l}\text { Type of } \\
\text { emission } \\
\text { source }\end{array}$ & $\begin{array}{c}\text { Source } \\
\text { height } \\
{[\mathrm{m}]}\end{array}$ & $\begin{array}{l}\text { Cross section / } \\
\text { area / volume of } \\
\text { the source }\end{array}$ & $\begin{array}{c}\text { \# of } \\
\text { sources }\end{array}$ & $\begin{array}{c}\text { Waste gas } \\
\text { temperature } \\
{\left[{ }^{\circ} \mathrm{C}\right]}\end{array}$ & $\begin{array}{c}\text { Relative } \\
\text { humidity of } \\
\text { waste gas [\%] }\end{array}$ & $\begin{array}{c}\text { Flow } \\
\text { rate } \\
{\left[\mathrm{m}^{3} / \mathrm{h}\right]}\end{array}$ & $\begin{array}{c}\text { Odour } \\
\text { concentration } \\
{\left[\mathrm{Ou}_{\mathrm{e}} / \mathrm{m}^{3}\right]}\end{array}$ & $\begin{array}{c}\text { Odour } \\
\text { emission rate } \\
{\left[0 \mathrm{u}_{\mathrm{e}} / \mathrm{s}\right]}\end{array}$ \\
\hline 5 & point & 1,5 & $1.45 \mathrm{~m}^{2}$ & 2 & 26.6 & 58 & 48.566 & 406 & 10.954 \\
\hline 6 & point & 6 & $0.50 \mathrm{~m}^{2}$ & 36 & 23.7 & 58 & 17.690 & 512 & 90.573 \\
\hline 7 & volume & 1 & $2.100 \mathrm{~m}^{3}$ & 1 & 17.5 & 62 & 1 & 16.402 & 1 \\
\hline 8 & area & 1,5 & $1.200 \mathrm{~m}^{2}$ & 1 & 24.3 & 51 & 4.920 & 64 & 87 \\
\hline 9 & point & 10 & $0.26 \mathrm{~m}^{2}$ & 1 & 31.0 & 49 & 6.176 & 2.048 & 3.513 \\
\hline 10 & point & 10 & $0.2 \mathrm{~m}^{2}$ & 1 & 29.7 & 46 & 2.334 & 142 & 92 \\
\hline 11 & point & 20 & $0.385 \mathrm{~m}^{2}$ & 1 & 42.1 & 27 & 8.472 & 29.670 & 69.823 \\
\hline 12 & point & 17 & $0.283 \mathrm{~m}^{2}$ & 1 & 87.9 & 100 & 626 & 781.456 & 135.886 \\
\hline 13 & point & 15 & $2.64 \mathrm{~m}^{2}$ & 3 & 31.6 & 47 & 7.968 & 14.596 & 96.917 \\
\hline 14 & point & 16 & $1.9 \mathrm{~m}^{2}$ & 11 & 27.6 & 54 & 1.402 & 287 & 1.229 \\
\hline 15 & point & 18 & $0.25 \mathrm{~m}^{2}$ & 7 & 24.5 & 60 & 13.428 & 114 & 2.977 \\
\hline 16 & area & 15 & $48 \mathrm{~m}^{2}$ & 1 & 27.6 & 70 & 1.440 & 512 & 205 \\
\hline 17 & area & 15 & $48 \mathrm{~m}^{2}$ & 1 & 26.8 & 81 & 1.440 & 271 & 108 \\
\hline 18 & area & 1 & $7.500 \mathrm{~m}^{2}$ & 1 & 12.1 & 87 & 30.750 & 303 & 2.588 \\
\hline 19 & point & 25 & $0.385 \mathrm{~m}^{2}$ & 1 & 31 & 74 & 9.286 & 917.204 & 2.365 .877 \\
\hline 20 & area & 0 & $2 \mathrm{~m}^{2}$ & 2 & 242 & 64 & 16 & 1.258 .200 & 11.184 \\
\hline
\end{tabular}

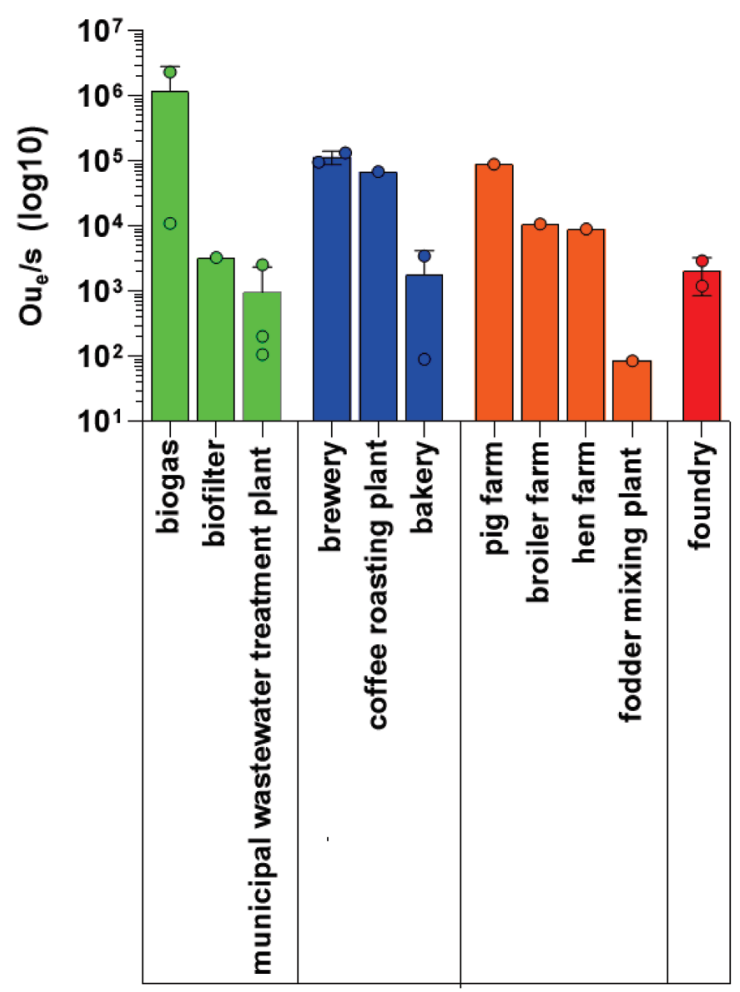

Fig. A1. Comparison of odour emission rates

Evaluation between groups of odour emission rates:

Column B: biogas, brewery, pig farm, coffee roasting plant (Sample size $n=4$ ) as highest measured emissions vs. Column A: rest/other (Sample size $n$ =11). At Fig. A2 actual values are on the horizontal axis, and the predicted values (assuming sampling from a Gaussian distribution) are on the vertical axis. Since the data were not sampled from a Gaussian (normal) distribution, the points were not following a straight line that matches the line of identity

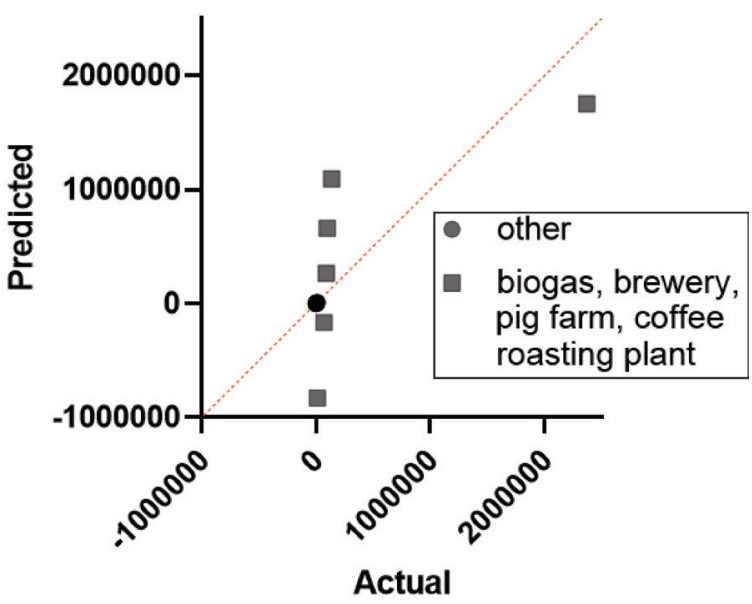

Fig. A2. QQ plot of a normality test (Column A, Column B);

Unpaired $t$ test:

where $P$ value is $0.0759, P$ value summary not significant (ns), not significantly different $(P<0.05)$, two-tailed $\mathrm{P}$ value, and $t=1.929$ and $d f=13$.

How big is the difference?

The mean of column $\mathrm{A}$ is 61023 while the mean of column B is 2554550. Difference between means (B A) \pm SEM is $2493526 \pm 1292932,95 \%$ confidence interval is between -299683 and $5286736 . R$ squared (eta squared) is 0.2225 . 
$\underline{F \text { test: }}$

To compare variances, where $F=2106$, $D F n=3, D f d=10, P$ value is $<0.0001$ and significantly different $(P<0.05)$.

Evaluation between groups of in-field odour concentrations using portable olfactometer:

Column A: P-F (Sample size $n=54$ ) as the highest measured concentrations vs. Column B: A-T and C-Z (Sample size $n=102$ )

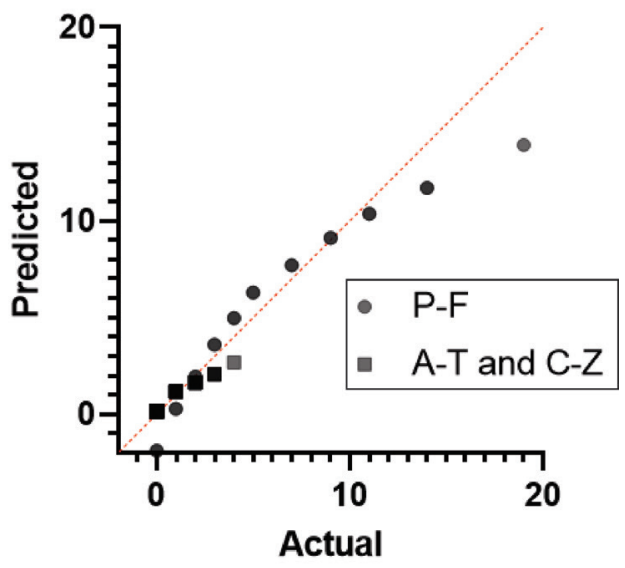

Fig. A3. This figure presents a QQ plot of the normality test (Column A, Column B)

At Fig. A3 actual values are on the horizontal axis, and the predicted values (assuming sampling from a Gaussian distribution) are on the vertical-axis. Since the data were sampled from a Gaussian (normal) distribution, the points were following a straight line that matches the line of identity

\section{Unpaired $t$ test:}

where $P$ value is $<0.0001$, significantly different $(P<0.05)$, two-tailed $P$ value, $t=10,52$ and $d f=154$.

How big is the difference?

The mean of column $\mathrm{A}$ is 4.704 , the mean of column B 0.4510 , the difference between means (B A) \pm SEM $-4.253 \pm 0.4042,95 \%$ confidence interval is between-5.051 and -3.454 and $R$ squared (eta squared) is 0.4182 .

$F$ test:

to compare variances: $F=20.59, D F n=53$, $D f d=101, P$ value is $<0.0001$ and significantly different $(\mathrm{P}<0.05)$.

\section{REFERENCES}

[1] Brancher, M., Griffiths, K.D., Franco, D., de Melo Lisboa, H. (2017). A review of odour impact criteria in selected countries around the world. Chemosphere, vol. 168, p. 1531-1570, DOI:10.1016/j.chemosphere.2016.11.160.

[2] EN 13725:2006. Stationary Source Emissions - Determination of Odour Concentration by Dynamic Olfactometry and Odour Emission Rate from Stationary Sources. European Committee for Standardization, Brussels.

[3] EN 16842:2016. Ambient Air. Determination of Odour in Ambient Air by Using Field Inspection - Part 1: Grid method. European Committee for Standardization, Brussels.

[4] Barret, K.E., Barman, S.M., Boitano, S., Brooks, H.L. (2012). Ganong's Review of Medical Physiology, McGraw-Hill, New York.

[5] Schauberger, G., Piringer, M., Petz, E. (2001). Separation distance to avoid odour nuisance due to livestock calculated by the Austrian odour dispersion model (AODM). Agriculture, Ecosystems \& Environment, vol. 87, no, 1, p. 13-28, DOI:10.1016/s0167-8809(00)00299-1.

[6] Janicke, L., Janicke, U., Ahrens, D., Hartmann, U., Müller, W.J. (2004). Development of the Odour Dispersion Model AUSTAL2000G in Germany. Environmental Odour Management, VDI-Berichte 1850, p. 411-417.

[7] Smith, M. (1973). Recommended Guide for the Prediction of the Dispersion of Airborne Effluents. American Society for Mechanical Engineers, New York.

[8] Beychok, M.R. (1979). Fundamentals of Stack Gas Dispersion. M.R. Beychok, Newport Beach.

[9] Piringer, M., Petz, E., Groehn, I., Schauberger, G. (2007). A sensitivity study of separation distances calculated with the Austrian Odour Dispersion Model (AODM). Atmospheric Environment, vol. 41, no. 8, p. 1725-1735, D0l:10.1016/j. atmosenv.2006.10.028.

[10] Piringer, M., Knauder, W., Petz, E., Schauberger, G. (2014). Site-dependent decrease of odour-related peak-to-mean factors with distance. Advances in Science and Research, vol. 11, p. 69-73, Dol:10.5194/asr-11-69-2014.

[11] Piringer, M., Knauder, W., Petz, E., Schauberger, G. (2015). A comparison of separation distances against odour annoyance calculated with two models. Atmospheric Environment, vol. 116, p. 22-35, Dol:10.1016/j.atmosenv.2015.06.006.

[12] Mylne, K.R. (1992). Concentration fluctuation measurements in a plume dispersing in a stable surface layer. Boundary-Layer Meteorology, vol. 60, p. 15-48, Dol:10.1007/BF00122060.

[13] Daoud, W.Z., Kahl, J.D.W., Ghorai, J.K., (2003). On the synopticscale Lagrangian autocorrelation function. Journal of Applied Meteorology, vol. 42, no. 2, p. 318-324, Dol:10.1175/15200450(2003)042<0318:0TSSLA>2.0.C0;2.

[14] Oettl, D., Ferrero, E. (2017). A simple model to assess odour hours for regulatory purposes. Atmospheric Environment, vol. 155, p. 162-173, D0l:10.1016/j.atmosenv.2017.02.022.

[15] VDI 3940, Part 1. 2006. Measurement of odour impact by field inspection - Measurement of the impact frequency of recognizable odour. Grid measurement. VDI-Verlag, Duesseldorf, Germany, GmbH.

[16] GOAA (2008). Determination and Evaluation of Odour Immissions - Guideline on Odour in Ambient Air -. Detection and Assessment of Odour in Ambient Air. (https://mma.gob. Cl/wp-content/uploads/2017/06/Detection-and-Assessmentof-Odour-in-Ambient-Air.pdf). 
[17] Gostelow, P., Parsons, S.A., Stuetz, R.M., (2001). Odour measurements for sewage treatment works. Water Research, vol. 35, no. 3, p. 579-597, D0l:10.1016/S00431354(00)00313-4.

[18] Watts, P.J., Sweeten, J.M. (1995). Toward a better regulatory model for odour. Proceedings of the $X^{\text {th }}$ Feedlot Association of Australia Conference, Benowa.

[19] Freeman, T., Cudmore, R. (2002). Review of odour management in New Zealand. Air Quality Technical Report 24. New Zealand Ministry of Environment, Wellington.

[20] Griffiths, K.D. (2014). Disentangling the frequency and intensity dimensions of nuisance odour, and implications for jurisdictional odour impact criteria. Atmospheric Environment, vol. 90, p. 125-132, D0I:10.1016/j.atmosenv.2014.03.022.

[21] Anfossi, D., Oettl, D., Degrazia, G.A. (2004). Some aspects of turbulence and dispersion in low wind speed conditions.
Air Pollution Modelling and Its Application XVI, p. 331-338, DOl:10.1007/978-1-4419-8867-6_30.

[22] Walgraeve, C., Van Hufffel, K., Bruneel, J., Van Langenhove, H. (2015). Evaluation of the performance of field olfactometers by selected ion flow tube mass spectrometry. Biosystem Engineering, vol. 137, p. 84-94, D0l:10.1016/j. biosystemseng.2015.07.007.

[23] Scire, J.S., Strimaitis, D.G., Yamartino, R.J. (2000). A User's Guide for the CALPUFF Dispersion Model. Version 5, Earth Tech, Inc., Concord.

[24] Scire J.S., Robe F.R., Fernau M.E., Yamartino R.J. (2000). A User's Guide for the CALMET Meteorological Model. Version 5 , Earth Tech, Inc.

[25] VDI 3882-2 (1994). Olfactometry - Determination of Hedonic Odour Tone. Verein Deutscher Ingenieure, Duesseldorf.

[26] VDI 3880 (2011). Olfactometry Static Sampling. Verein Deutscher Ingenieure, Duesseldorf. 